\title{
Legal Determinants of External Finance Revisited: The Inverse Relationship Between Investor Protection and Societal Well-Being
}

\author{
David Collison • Stuart Cross • John Ferguson • \\ David Power • Lorna Stevenson
}

Received: 3 March 2011/ Accepted: 7 September 2011/Published online: 9 November 2011

(C) Springer Science+Business Media B.V. 2011

\begin{abstract}
This article investigates relationships between countries' legal traditions and their quality of life as measured by a number of widely reported social indicators; in so doing it also offers a critique of a highly influential body of work which is widely cited in the literatures of corporate governance, economics and finance. That body of work has shown, inter alia, statistically significant relationships between legal traditions and various proxies for investor protection. We show statistically significant relationships between legal traditions and various proxies for societal health. Our comparative evidence suggests that the interests of investors are not congruent with the interests of wider society, and that the criteria for judging the
\end{abstract}

D. Collison $(\varangle) \cdot$ D. Power - L. Stevenson

School of Business, University of Dundee,

Dundee DD1 4HN, Scotland, UK

e-mail: d.j.collison@dundee.ac.uk

D. Power

e-mail: d.m.power@dundee.ac.uk

L. Stevenson

e-mail: 1.a.stevenson@dundee.ac.uk

S. Cross

School of Law, University of Dundee,

Dundee DD1 4HN, Scotland, UK

e-mail: s.r.cross@dundee.ac.uk

J. Ferguson

Department of Accounting \& Finance,

University of Strathclyde, Curran Building,

100 Cathedral Street, Glasgow G4 0LN,

Scotland, UK

e-mail: john.ferguson@strath.ac.uk effectiveness of approaches to corporate governance should be broadened.

Keywords Legal traditions - Social indicators · Social accounting - Investor protection .

Corporate governance

\section{Introduction}

The most influential contribution to the literature on international corporate governance (Solomon 2007) is that made in a series of papers by La Porta, Lopez-De-Silanes, Shleifer and Vishny (see, for example, La Porta et al. 1996, 1997a, 1998, 2000a, b, 2002, 2006, 2008; Shleifer and Vishny 1997). The extent of their contribution to the fields of banking, economics, finance and law is also particularly noteworthy. According to "in-cites" (an editorial component of Essential Science Indicators published by Thomson Scientific), the four most influential authors in the world in the area of economics and banking in 2007 were Shleifer (with 3,765 citations), Lopez-DeSilanes (with 2,396 citations), La Porta (with 2,394 citations) and Vishny (with 1,531 citations). In a recent classification of the most cited articles in finance from 2000 to 2006, three of the top five papers are contributions by this group (Keloharju 2008). Their key papers have influenced research across disciplinary boundaries being "some of the most-cited pieces in economics, finance and law" (Siems 2005). Referring specifically to La Porta et al. (1998), Braendle (2006) states that this article "has been and is still cited frequently and usually uncritically, in legal as well as in economic journals" 
(p. 261) and "[it] is a standard reference in comparative corporate and financial law" (p. 263). ${ }^{1}$

La Porta et al. investigated, in particular, relationships between legal traditions and corporate governance systems, especially with regard to differing levels of investor protection and their consequences. Their early papers (La Porta et al. 1997a, 1998) developed the proposition that stock market size and consequent economic development were promoted by a legal system which protected the interests of outside investors against appropriation by insiders; and they viewed this argument, following Jensen and Meckling (1976), as a natural consequence of a "contractual view of the firm" (La Porta et al. 2008). They are now widely identified with the presumption that common law legal traditions lead to better economic outcomes than those based on civil law.

In this article, we highlight the arguably narrow ethical perspective underpinning their work by widening their analysis to consider social as well as economic outcomes. Such an extension of their findings is, we feel, particularly important, given the wide ranging and largely unquestioning use to which their results have been put; for example, Braendle (2006) claims that "the blindfold citation" of La Porta et al.'s 1998 paper "seems very common" (p. 278). See also, for example, Chui et al. (2002).

In particular, it is arguable that their work has contributed to the marginalisation of a stakeholder orientated approach to corporate governance which tends to be identified with practice in civil law countries. For example, Dignam and Galanis (2008) claim that a significant turning point in the stakeholder/shareholder debate within the governance literature was marked by the publication of the series of papers in the late 1990s by La Porta et al. According to Dignam and Galanis (2008, p. 3) "their work contributed significantly to later claims for the superiority of the outsider system". In this sense, their work has played a significant part in the development of a conventional

\footnotetext{
1 Two citation indexes were consulted in order to provide an overview of the influence of La Porta et al.'s research, in particular, their 1997a and 1998 studies. In January 2010, a search of the ISI Web of Knowledge citation database yielded 831 citations for La Porta et al. (1997) and 1,291 for La Porta et al. (1998). A similar search on Harzing's Publish or Perish programme (Jan 2010), downloaded at http://www.harzing.com/, yielded 2,729 and 3,975 citations, respectively. The ISI web of knowledge database is drawn from a selected group of influential journals, while The Publish or Perish programme uses data from Google Scholar. According to Keloharju (2008), a Publish or Perish search is more reliable for the assessment of a paper's impact, since it includes both published articles and working papers. Arguably, the influence of this group of authors extends beyond citations to their published research. For example, both La Porta and Lopez-de-Silanes have been the economic advisors to the National Banking and Stock Market Commission in Mexico. Further, Lopez-de-Silanes has held advisory/consultancy roles with The World Bank and the International Monetary Fund.
}

wisdom that the "Anglo-American" shareholder-value oriented form of corporate governance is the model to which other jurisdictions should conform (see, for example, La Porta et al. 2008; Aguilera and Jackson 2003; Collison 2003; Hansmann and Kraakman 2001). For example, Milhaupt (2005, p. 2199) notes that the central explanation from La Porta et al.'s body of work is that "common law systems appear to provide better investor protections than civil law-particularly French civil law-systems. It is plausible that as a result, the Anglo-American economies have larger capital markets and faster economic growth than economies supported by European civil law". 2 The claims of La Porta et al. which have been characterised as the "legal origins hypothesis" have also been significant for policy formulation. According to Ahlering and Deakin (2007, p. 866), their claims have been: "highly influential, not least in informing the policy and working methods of the World Bank and other international financial institutions". Furthermore, Armour et al. (2010), notwithstanding their view that La Porta et al.'s methods are contestable, state that the "legal origins hypothesis is one of the most important and influential ideas to emerge in the social sciences in the past decade" (p. 2).

In sum, La Porta et al.'s statistical analysis has shown that the origin of a country's legal system is associated with levels of investor protection, and the degree to which its capital markets are developed. They show that countries sharing a common law legal tradition (such as UK, US and the other developed English-speaking economies) have greater levels of investor protection, larger capital markets with more dispersed ownership, and a greater propensity for funds to be committed to new enterprises by external investors. In La Porta et al. (1998), the authors also draw on other literature to show that such phenomena are associated with greater economic growth. In more recent work, however, La Porta et al. (2008) noted, citing Glaeser et al. (2004), that "the evidence on the relationship between institutions and aggregate growth more generally, which seemed substantial a few years ago, has been crumbling" (p. 302). Indeed, Ahlering and Deakin (2007) robustly state that there is "no sound basis for the argument that the common law is more conducive to economic growth than the civil law (p. 868). Notwithstanding such observations, the main edifice of the La Porta et al. work is still regarded as robust by its authors: "our framework suggests that the common law approach to social control of economic life performs better than the civil law approach" (La Porta et al. 2008, p. 327).

\footnotetext{
${ }^{2}$ Milhaupt (2005, p. 2199) adds, "The genius of Delaware law - the best of the best - shines bright in the wake of this literature. Not surprisingly, commentators are beginning to explore ways to adapt features of Delaware law to foreign systems".
} 
In this article, we revisit some of the key statistical findings reported by La Porta et al., widen the work's scope and reveal that the civil and common-law traditions which they highlight also show statistically significant associations, amongst developed economies, with various measures of societal well-being. We call into question the criteria used by La Porta et al. for assessing laws as "poor", by taking a broader perspective on a country's performance than one which focuses on financial and economic metrics. We also consider the differences between common and civil law to suggest a rationale for the results that we find, and for those reported by La Porta et al. In particular, we draw on arguments developed by Berle and Means (1932) regarding the provenance and implications of civil and common-law traditions. Our main focus in this article is on two of the earlier La Porta et al. papers, especially La Porta et al. (1997a) and also La Porta et al. (1998). Not only are these two of their most cited pieces of work, but also the structure of the 1997 paper serves as a convenient basis for the statistical comparison that is at the heart of this article. While our main focus is on the 1997 paper, $^{3}$ we will also adduce perspectives and more recent findings from their later work ${ }^{4}$ especially La Porta et al. (2008).

The remainder of this article is structured as follows. In the next section, we outline relevant parts of the La Porta et al. work and the reference they make to the classic agency analysis of Berle and Means (1932); we also consider evidence of their influence in the corporate governance literature. The subsequent section considers the relevance of social indicators as a method of assessing a country's well-being, and reports our analysis of certain indicators using the same method of country classification (i.e. one based on legal origin) as that used, in particular, by La Porta et al. (1996, 1997a, 1998). In that section, we reproduce material contained in La Porta et al. (1997a). The final section considers possible explanations for our findings based on the nature of the common and civil law legal traditions and offers some conclusions. Our fundamental aim in this article is to investigate, by drawing on the work of La Porta et al., the evidence for a relationship

\footnotetext{
3 A modified version of the title of the La Porta et al. (1997a) paper, i.e. "Legal Determinants of External Finance" is the title of the current article.

4 As pointed out in the La Porta et al. body of work, especially La Porta et al. (2008), some refinements have been made by the authors to the variables which they used in the 1997a and 1998 analysis. We think that it may be helpful if the figures which we quote from La Porta et al. (1997a) are identifiable from that classic paper. Therefore, in this article, we have reproduced some of the 1997 data as originally published; i.e. without adjustment for the subsequent refinements. We do not believe that updating La Porta et al.'s earlier data would have any bearing on the evidence and the arguments that we put forward in the current study.
}

between countries' legal traditions and their quality of life as measured by certain social indicators. A complementary aim is to challenge the extremely influential conclusions reached by La Porta et al. regarding the putative superiority of the common law, or Anglo-American, approach to "the social control of economic life".

\section{Common and Civil Law Legal Traditions and the Work of La Porta et al.}

In the introduction to this article, we suggested that the work of La Porta et al. lends itself to normative arguments in support of an approach to corporate governance based on a narrow agency theory perspective (Dignam and Galanis 2008; Milhaupt 2005). This is consistent with the AngloAmerican, shareholder value-based model of capitalism as opposed to a stakeholder or social market-based approach. The "varieties of capitalism" literature (see, for example, Hall and Soskice 2001; Dore 1999, 2000, 2006; Hutton $1995,2003)$ is extensive and a substantive review of it would go beyond the scope of this article. But it seems apposite to note that, in their much cited work, Hall and Soskice (2001) take a "firm-centered" approach and regard "companies as the crucial actors in a capitalist economy" (p. 6). They apply micro level concepts to help understand the macro economy. Hall and Soskice draw a distinction between the two types of political economies, which they term as liberal market economies and coordinated market economies, respectively. While they describe these ideal types as "poles of a spectrum" they broadly correspond to the classification used in this article between AngloAmerican and social market forms of capitalism. La Porta et al. (2008, p. 303) cite the observation from Pistor (2006) that "all the liberal market economies in the OECD are common law countries, and all the coordinated ones are civil law ones". They then add "The literature on the variety of capitalisms has long looked for an objective measure of different types; perhaps it should have looked no further than legal origins".

We should emphasise that La Porta et al. do not themselves adversely compare the generic "stakeholder model" of capitalism with the "shareholder model"; at least they do not do so explicitly. It is a question on which they appear to be silent: certainly the term "stakeholder" does not appear in any of their papers which are cited above. Shleifer and Vishny (1997) do note "several important topics closely related to corporate governance that [their] article does not deal with" (p. 740). These are "the foundations of contract theory", the "basic elements of the theory of the firm", "noncapitalist ownership patterns" (although they state that "we pay some attention to cooperatives") and certain functions of "financial 
intermediaries". Given this careful exclusion of "important topics" related to corporate governance, their silence on stakeholders in conventionally owned firms is a rather deafening one.

In their widely cited survey of corporate governance, Shleifer and Vishny (1997) were very clear regarding their criteria for judging corporate governance:

Our perspective on corporate governance is a straightforward agency perspective, sometimes referred to as separation of ownership and control. We want to know how investors get managers to give them back their money. (p. 738)

They go on to make clear that they regard the principal question in relation to corporate governance systems as being not whether particular governance systems should be copied, but rather how external providers of finance can be provided with legal protection such that large-scale financing of entities can develop. They emphasise that this is neither the case in many developing countries, nor in some "rich European countries" (p. 738). Elsewhere in their paper they assert that "The fundamental question of corporate governance is how to assure financiers that they get a return on their financial investment." (p. 773, emphasis added)

Shleifer and Vishny (1997) emphasised the absence of a basis on which to judge corporate governance models. For example, in relation to the United States, Germany and Japan, they state that "all these economies have the essential elements of a good corporate governance system", and that "the available evidence does not tell us which one of their governance systems is the best" (Shleifer and Vishny 1997, p. 739, emphasis in original). The ensuing body of work from La Porta et al. does however go on to develop a view of which system, based on levels of investor protection, is best, and that, as indicated above, turns out to be a common-law system (corresponding to the Anglo-American version of capitalism).

Berle and Means' classic analysis, which focuses on the agency conflict between ownership and control, is cited as part of a recurring theme in a number of the La Porta et al. papers (see, especially, La Porta et al. 1999b). That theme is the need to reappraise a common image of corporate structures; La Porta et al. state that "Our results present a different picture of the ownership structure of a modern corporation than that suggested by Berle and Means and widely accepted in the finance literature." (La Porta et al. 1999b, p. 502). In brief, La Porta et al. (see, especially, La Porta et al. 1999b) argue that, for many companies, there is a more significant agency problem than that based on the separation of ownership and control. They identify this as the risk to minority shareholders of expropriation by majority shareholders. They see this risk as being particularly acute in family controlled companies associated with "insider" economies:
Who keeps the controlling families from expropriating the minority shareholders, especially in countries with weak legal protection of these shareholders, where family control is even more common? Who monitors the families? (emphasis in original) (La Porta et al. 1999b, p. 502)

Hence, the degree of legal protection of minority shareholders is an important criterion in much of their empirical analysis. To sum up their position we again quote from La Porta et al. (1999b):

large firms have a problem of separation of ownership and control, but not the one described by Berle and Means. ... controlling shareholders ... have the power to expropriate the minority shareholders as well as the interest in so doing. (La Porta et al. 1999b, p. 511)

However, there is another, more fundamental, insight of Berle and Means on which La Porta et al. appear to be silent, and which is an explicit critique of the common law tradition and its implications for corporate governance.

In their discussion of "The traditional logic of property", Berle and Means (1932, Book Four, Chap. 1), refer to legal, economic and social issues "which must now be squarely faced". The most important issue that they identify is "who should receive the profits of industry", in other words, should large companies be run in the interests of the "owners" or others? Berle and Means place quotation marks around the word "owners" to indicate the problematic issue of identifying the meaning of, and the rights attaching to, ownership of large and publicly important enterprises. They assert that under common law, the traditional logic of property requires that the entire profit be awarded to the shareholders. They discuss the historical development of the law pertaining to property when power to manage assets is delegated to others. The dominant tradition is that those with delegated rights to control assets owned by others do so as fiduciaries. They follow their examination of such developments by stating:

Underlying all this is the ancient preoccupation of the common law with the rights of property. Primarily, the common law did not undertake to set up ideal schemes of government. It aimed to protect men in their own. (Berle and Means 1932, p. 296)

This legal tradition is subjected to a critical reappraisal by Berle and Means. In this exercise they address fundamental questions arising from the separation of ownership and control. However, their interest in this question was not confined to the classic agency problem with which they are closely associated - they were much more concerned with the significance for wider society of the operation of large 
corporations (Gomez and Korine 2005). Berle and Means consider that the owners of passive property, having given up the role of managing their resources, have also given up the right to have the entity operated in their interest ${ }^{5,6}$. But they are also emphatic that the elimination of the "sole interest of the passive owner" does not mean that the controlling group should take over the same right: they conclude that neither "the claims of ownership nor those of control can stand against the paramount interests of the community". They recognize that institutional and political accommodations will need to be fashioned, but hold that:

When a convincing system of community obligations is worked out and is generally accepted, in that moment the passive property right of today must yield before the larger interests of society. (p. 312)

Berle and Means (1932) envisage courts having to moderate their traditional position on property rights by whichever "legal theories they might choose" to recognize what the authors see as a social imperative. We suggest that their views of the differing characteristics of a legal framework which aims to balance the interests of all members of society, and the common law which merely seeks to defend "men in their own" are of particular significance in assessing the work of La Porta et al.

La Porta et al. (1996/1998-hereafter 1998 ${ }^{7}$ ) investigated the legal rules offering protection to shareholders and creditors in 49 countries. They examined the origin of these countries' different legal systems, and the extent to which

\footnotetext{
5 Macintosh (1999, p. 139) examines the celebrated exchange between Adolf A. Berle Jr and E. Merrick Dodd Jr in the early 1930s, in which Berle argued "that the management of a corporation could only be held accountable to shareholders... whereas Dodd held that corporations were accountable to both the society in which they operated and their shareholders". Clearly, Berle's position within this debate does not fit squarely with the conclusions outlined by Berle and Means (1932), which demand that modern corporations serve all of society. However, both Macintosh (1999, p. 146) and Ireland (2001, p. 150) point out that Berle's position within this debate changed and that he began to acknowledge the "validity of Dodd's views". While Macintosh (1999) suggests the change in Berle's perspective became evident in the 1950s, Ireland (2001) suggests that, "by the time of the publication of The Modern Corporation and Private Property in late 1932 Berle's own position had begun to shift."

${ }^{6}$ In the General Theory, Keynes (1936) famously went somewhat further than Berle and Means in his disdain for rewarding the passive investor. He advocated (metaphorically) "the euthanasia of the rentier, of the functionless investor" (p. 235) and the consequent "euthanasia of the cumulative oppressive power of the capitalist to exploit the scarcity value of capital".

${ }^{7}$ La Porta et al. (1998) is the later (published) version of a working paper which appeared in 1996 . The 1996 version is referred to in the 1997a paper, the latter being to an extent a development of it. The sequence of the La Porta et al. work may not be apparent unless this is made clear. As indicated in the text our main focus in the current paper is La Porta et al. (1997a).
}

shareholders' and creditors' rights were enforced. Their basic classification of legal systems was twofold-those comprising common law with English origins and those based on civil law deriving from Roman law. They further classified the civil tradition countries (drawing on Reynolds and Flores 1989), into the "three major families": French, German and Scandinavian legal traditions. They noted that English common law and the French and German varieties of civil law had spread to many other countries through a variety of mechanisms including colonialism and "more subtle imitation". The number of countries in each group was, 18 in the English origin group; 21 in the French origin group; six in the German origin group and four in the Scandinavian group, respectively.

Their investigation of legal regimes showed that common law countries generally offer stronger legal protection for investors than their civil law counterparts. Amongst the civil law groupings the weakest legal protection for investors was found in the French civil law countries, with the German and Scandinavian civil law countries in between the French civil law and common law groups. Another key finding reported by La Porta et al. (1998) was that weaker investor protection is associated with more concentrated share ownership. Consequently, they hypothesized that stronger legal protection is likely to mean that a larger proportion of shares will be held in the form of minority holdings by diversified shareholders.

The latter hypothesis is supported by the findings reported in La Porta et al. (1997a) which show that countries with weaker investor protection have "smaller and narrower" capital markets for both equity and debt. They highlight the French civil law countries as having "both the weakest investor protections and the least developed capital markets" (p. 1131) especially as compared with common law countries.

La Porta et al. (1997a) acknowledge that they have refrained from asking "deeper questions" about why differences exist between common and civil law countries in relation to investor protection. (Although La Porta et al. (2008) does include a searching exploration of the historical antecedents of the common and civil law traditions.) They pose the question: "what is it about the civil law family, and particularly about the French civil law sub family, that accounts for the relative unfriendliness of laws to investors?" (p. 1149). Their speculations include the possibility of pure coincidence, or active legal design aimed at keeping "investors relatively weak, and to assure family firms and the state a larger role in economic development?". They also speculate about whether "poor laws are just a proxy for an environment that is hostile to institutional development" and, drawing on evidence in La Porta et al. (1997b), suggest that countries which have low levels of trust among their citizens have less effective 
institutions. In particular they wonder whether "some broad underlying factor, related to trust" may influence all institutions in a country including legal systems and capital markets. $^{8}$

In La Porta et al. (1998), the authors also seek to place their findings in a wider context and pose "the ultimate question" of "whether countries with poor investor protections ... actually do suffer" (p. 1152). This question is partially answered by reference to work cited by King and Levine (1993) and Levine and Zervos (1998) which found that "developed debt and equity markets contribute to economic growth". La Porta et al. (1998) also highlighted evidence from Levine (1998) who confirmed the King and Levine as well as the Levine and Zervos findings when the analysis was extended to incorporate a La Porta et al. "legal origin variable". La Porta et al. also cited Rajan and Zingales (1995) who found that growth in capital intensive industries was related to the level of development of financial systems. Thus, La Porta et al. (1998) identified a link from the legal system of a country to its level of economic development, while acknowledging that the obstacles to growth created by poor investor protection had not prevented certain countries (they mention, in particular, France and Belgium) from becoming rich. The evidence regarding the link between legal tradition and economic growth has been reassessed by La Porta et al. (2008) but, ten years later, their perspective on the significance of legal regimes was summed up as follows:

In sum, there is by now a great deal of evidence that legal origins influence legal rules and regulations, which in turn have substantial impact on important economic outcomes-from financial development, to unemployment, to investment and entry, to the size of unofficial economy, to international trade. Much of this evidence suggests that common law is associated with better economic outcomes than French civil law. The evidence also shows that legal origins influence patterns of growth within industries, but it is less clear that legal origins predict aggregate growth. The last finding resonates with the obvious observation made by LLSV [La Porta et al.] (1998) that countries like France and Belgium achieved high living standards despite their legal origin. (La Porta et al. 2008, p. 302)

In this article, we take issue with the criterion, namely economic growth, used by La Porta et al., at least in their earlier work, to address the "ultimate question" of whether countries with poor investor protection "do suffer". The

\footnotetext{
${ }^{8}$ In his examination of happiness, Layard (2005), drawing on Putnam (2000) reported that in continental Europe "levels of trust have improved (or not fallen) in every country since 1980" whereas, over a broadly comparable period, levels of trust had steadily declined in UK and US.
}

fact that subsequent evidence on that specific issue is unclear is beside the point. We take a broader social perspective in which economic growth is regarded as a means to an end, not an end in itself. Answering our "ultimate question" relies on the criterion of societal well-being rather than the "better economic outcomes" referred to by La Porta et al. Of course there may not be a clear consensus on how societal well-being should be measured, although the same argument could be advanced about economic growth. There are, however, increasingly widely reported and authoritative social indicators which do inform such judgments (see, for example, the United Nations' annual Human Development Reports and UNICEF's annual State of the World's Children Reports 2004). In the next section, we shall briefly discuss the development and use of social indicators and argue that they reveal a very different perspective on the relative performance of common and civil law countries from that put forward by La Porta et al.

\section{Social Indicators and an Extension of the La Porta et al. (1997a) Analysis}

In the 1960s and early 1970s, a 'social indicators movement' arose as a result of the perceived inadequacy of the information available to policy makers (Carley 1981; see also Glatzer 1981) to promote human welfare under circumstances of significant economic growth. In Bauer (2006, cited in Glatzer 1981) the concept of social indicators was "elaborated for the first time" (Glatzer 1981) although Glatzer also points out that the same fundamental concepts had also received attention from the United Nations in the 1950s. The suitability of macroeconomic metrics as indicators of societal welfare was increasingly questioned based on a growing body of research (see, for example, Christian 1974; Galnoor 1974; Goeke 1974; Liu 1974; Seashore 1974). The field of enquiry into social indicators burgeoned and the early 1970s saw the inception of the specialist journal, Social Indicators Research. Indeed, only a few years later, Glatzer (1981) stated that its "breadth and diversity" meant that "no one social scientist can hope to provide an adequate survey of the relevant literature." By 1976, the OECD had reported that:

growth is not an end in itself, but rather an instrument for creating better conditions of life [and] increased attention must be given to the qualitative aspects of growth, and to the formulation of policies with respect to the broad economic and social choices involved in the allocation of growing resources. (OECD 1976, p. 7)

Arguably the interest in social indicators, certainly as regards the developed economies, reached a high water mark in the 1970s, mirroring, to some extent, progressive 
developments in the field of corporate accountability at that time (see for example, ASSC 1975; Burchell et al. 1985; Gray et al. 1995). Soon afterwards, there were fundamental changes in the political climate (see, for example, Day and Woodward 2004; Woodward et al. 2001) and since then, at least within the "common law" countries, economic metrics have been "regnant" (Diener and Suh 1997) as reflected, we would argue, in the criteria used by La Porta et al. In the current article we report on a subset of the indicators published annually by the United Nations and, like La Porta et al., we consider the entity of interest to be the nation state.

\section{La Porta's 1997 Analysis Revisited with Social Indicators}

In this article, we have followed a similar pattern for the presentation of data to that used in La Porta et al. (1997a). In Table II of that paper (p. 1138), they listed 49 countries, grouped by legal origin, and reported empirical measures of financial and legal variables with means calculated for each legal origin. Our equivalent to Table II in La Porta et al. (1997a) is Table 2; it differs from the La Porta et al. Table II in three ways. First, we have added a number of social indicator variables. The social indicators comprise: the under 5 child mortality rate (U5MR 01-04); two separate measures of income inequality (R10/P10 - based on the richest and poorest deciles, and the Gini index — based on income distribution across the whole population); the log of the prison population (Log Pr Pop) and the proportion of women in the lower, or a single, house of legislators (\% Women MPs). These variables are defined in more detail in Table 1a.

Second, we have restricted the number of countries investigated. The 49 countries considered by La Porta et al. span a very wide range of social and economic development. Had we used the same list of countries, any associations that may exist between social indicators and legal origins may well have been masked by the very large differences attributable to other factors. Such masking would be especially relevant to health indicators which show gross discrepancies between rich and poor countries lying on opposite sides of the "epidemiological transition". 9,10 Our choice of countries is, therefore, a subset

\footnotetext{
9 The epidemiological transition is a significant stage in the relationship between health and economic development; it occurs where increased prosperity allows the eradication of many infectious diseases and other readily preventable causes of illness and death. As Kohn (2001, p. 40) states: "Above this transition point, absolute wealth makes little difference to life expectancy".

${ }^{10}$ Two previous studies have addressed, to a limited extent, links between the work of La Porta et al., on legal origins, and certain social indicators (La Porta et al. 1999a; Ahlering and Deakin 2007, pp. 890-891). In both cases, no account was taken of the potentially confounding effects of the fundamentally different relationships between per capita wealth and social indicators on either side of the
}

of the 49 investigated by La Porta et al. and is based on the method adopted by Collison et al. (2007) which investigated child mortality in wealthy nations. In order to compare rich countries on the same side of the epidemiological divide, Collison et al. (2007) restricted their examination to the 24 wealthiest OECD countries. Of those 24, only 22 are included in the current analysis since two, Iceland and Luxembourg, were not included in the La Porta et al. study. The restriction in the number of countries has not altered the relative outcomes originally recorded by La Porta et al. Their aggregated ranking of countries, when grouped by legal origin, persists when their data is restated for the smaller group of developed OECD countries. Both sets of aggregated figures, for the larger and smaller groups, are shown in bold in Table 2 .

Third, we have reported in Table 2 only a subset of the indicators from La Porta et al. (1997a). The indicators reported are those from the first four columns of Table II in La Porta et al., and they measure various proxies for shareholder protection and the vitality of equity markets. This has been done to aid clarity of the exposition. The definitions of these variables are reproduced, in summary form, in Table 1b. The rest of the financial/legal variables considered by La Porta et al. (1997a) are reproduced in an Annex to this article (in "Supplement to Table 1b" and "Supplement to Table 2") and they are also included in statistical investigations which appear later in the article.

The basis of the choice of the social indicators listed in Table 1a, merits some explanation. Results reported in Collison et al. $(2007,2010)$ highlighting the poor performance of the Anglo-American countries suggested the possibility of an underlying systemic relationship involving poor societal well-being which could be linked to income inequality. The epidemiological literature provides additional evidence to support such a proposition (see, for example, Wilkinson and Pickett 2009). Two measures of income inequality were chosen and are explained in more detail in Table 1 . They are the widely used Gini coefficient which takes into account income levels across an entire population, and a second, more extreme, measure which is a ratio based only on the income received by the top and bottom population deciles. The child mortality and prison population variables were chosen as examples of indicators which previous research had shown to be related to income inequality (see, for example, Wilkinson and Pickett 2009). The percentage of women MPs was selected since it seemed to be a potential discriminator between common and civil law traditions; the former being identified with the

\footnotetext{
Footnote 10 continued

"epidemiological transition", In particular the widely reported relationship, for wealthier countries, between income inequality and a range of social indicators was not examined in these studies.
} 
Table 1 Description of the social indicators (a) and summarised description of the variables reported in Table 1 of La Porta et al. (1997a) (b)

(a)

U5MR 01-04

$\mathrm{R} 10 / \mathrm{P} 10$

Gini index

Log Pr Pop

$\%$ Women MPs

(b)

Ext cap/GNP

Domestic firms/pop

IPOs/pop

AntiDir Rights
Mean under 5 child mortality rate for the years 2001-2004. Source UNICEF's State of the World's Children Reports 2003-2006.

The ratio of the income or expenditure share of the richest $10 \%$ of a population to that of the poorest 10\%. Source UN Human Development Report (HDR) 2007-2008.

Gini coefficient of income inequality. Source UN HDR 2007-2008. This measure, unlike the R10/P10 ratio, is based on income levels for an entire population.

Log of prison population as at January 2007. Source HDR 2007-2008.

Percentage of Women in lower or single house of legislators as at 31 May 2007. Source HDR 2007-2008.

The ratio of the stock market capitalisation held by minorities to gross national product in 1994 .

Ratio of the number of domestic firms listed in a given country to its population (in millions) in 1994. Source: emerging market fact book and world development report 1996.

Ratio of the number of initial public offerings of equity in a given country to its population (in millions) for the period July 1995 to June 1996.

An index aggregating shareholder rights.

Note that the data reported in this table are not all from the same year as each other or as the data reported in the La Porta et al. (1997a) study. The figures on child mortality have been taken from the Collison et al. (2007) paper for consistency with that set of data. (It should be noted that more recent child mortality figures based on the years 2005-2007 have also been confirmed as showing comparable statistically significant correlations with income inequality (Collison et al. 2010)). The differences in base year relative to the La Porta et al. (1997a) study are arguably appropriate in principle, since one could regard social indicators as being a lagging variable relative to economic indicators, though the ideal time differences for an examination such as this are moot. Furthermore, we would not expect the figures and relationships under consideration to be very sensitive to such timing issues

preservation of established interests. It seemed plausible that such values could be manifested in various ways:

If the mechanics of a particular electoral system exclude to a large degree members of a particular ascriptive group (women or otherwise), then more often than not that is damning evidence that the system is excluding the interests of that particular group from the structures of decision-making power....Indeed, the degree to which a system successfully includes women can indicate a propensity for the system to include other disenfranchised minorities. (Reynolds 1999, p. 549)

The statistical significance of the relationships between social indicators and legal origin and between social indicators and some of the specific measures related to investor protection used by La Porta et al. are examined in some detail below. But a number of striking patterns emerge from a visual inspection of the mean statistics for the social indicators chosen. Consistent with the results from Collison et al. $(2007,2010)$, the common law (i.e. English origin) countries have the worst child mortality figures and the highest levels of income inequality. The common law countries also have the largest mean prison population in the OECD and this result too is consistent with findings reported by Wilkinson and Pickett (2009) that "more unequal countries have higher rates of imprisonment than more equal countries" (p. 148).

The association of income inequality with a range of social ills which is now widely established in the epidemiological literature is reflected in the consistent ranking of the legal origin groups across the income inequality, child mortality and prison population indicators. In each case, the Scandinavian countries perform best, followed by the German group. The French group is consistently ranked third while the common law countries are consistently ranked at the bottom. ${ }^{11}$

11 Although not addressing social indicators per se, Chih et al. (2010) consider the "determinants" of Corporate Social Responsibility, and utilise La Porta et al.'s (1998) “Shareholder Rights and Legal Enforcement" indices in their analysis. They find that, "interestingly and rather strikingly, those firms in countries with stronger investor rights engage in less CSR activities" (p. 132). They suggest that, "stronger shareholder rights are found to have the negative impact on the incentives of firms to engage in CSR activities, since financial firms in countries with stronger shareholder rights may tend to be geared toward shareholders' welfare at the expense of fulfilling their obligations to other stakeholders" (p. 132). However, drawing on La Porta et al. (1999a, b), Jackson and Apostolakou (2010, p. 388), report that firms engage in greater levels of CSR where shareholder protection is stronger. They state, "Firms appear to adopt CSR to compensate for strong shareholder rights by embedding these within broader social commitments... findings suggest that the adoption of CSR practices, particularly on the social dimension, emerges as a substitute for formal participation of employees only in parallel to the expansion of legal rights for shareholders or growing orientation of shareholder value by corporate management" (p. 388). Of course, comparisons of CSR activities are hampered by definitional and measurement problems due to differing visibilities and institutional contexts (see for example, the consideration of implicit and explicit CSR by Matten and Moon (2008)). Furthermore, as alluded to by Jackson and Apostolakou, CSR may be associated with instrumental motives in liberal market economies. 
Table 2 External capital markets and social indicators

\begin{tabular}{|c|c|c|c|c|c|c|c|c|c|}
\hline Country & $\begin{array}{l}\text { ExtCap/ } \\
\text { GNP }\end{array}$ & $\begin{array}{l}\text { Domestic } \\
\text { firms/Pop }\end{array}$ & $\begin{array}{l}\text { IPOs/ } \\
\text { Pop }\end{array}$ & $\begin{array}{l}\text { AntiDir } \\
\text { rights }\end{array}$ & $\begin{array}{l}\text { U5MR } \\
01-04\end{array}$ & $\begin{array}{l}\text { R10/ } \\
\text { P10 }\end{array}$ & $\begin{array}{l}\text { Gini } \\
\text { index }\end{array}$ & $\begin{array}{l}\text { Log Pr } \\
\text { Pop }\end{array}$ & $\begin{array}{l}\text { \% Women } \\
\text { MPs }\end{array}$ \\
\hline Australia & 0.49 & 63.55 & - & 4 & 6 & 12.5 & 35.2 & 2.10 & 24.7 \\
\hline Canada & 0.39 & 40.86 & 4.93 & 4 & 6.5 & 9.4 & 32.6 & 2.03 & 20.8 \\
\hline Ireland & 0.27 & 20 & 0.75 & 3 & 6 & 9.4 & 34.3 & 1.86 & 13.3 \\
\hline New Zealand & 0.28 & 69 & 0.66 & 4 & 6 & 12.5 & 36.2 & 2.27 & 32.2 \\
\hline UK & 0.49 & 35.68 & 2.01 & 4 & 6.5 & 13.8 & 36.0 & 2.09 & 19.7 \\
\hline USA & 0.39 & 30.11 & 3.11 & 5 & 8 & 15.9 & 40.8 & 2.87 & 16.3 \\
\hline English origin avg & 0.50 & 43.2 & 2.29 & 4 & 6.5 & 12.3 & 35.9 & 2.20 & 21.2 \\
\hline La Porta et al. avg ${ }^{\mathrm{a}}$ & 0.60 & 35.45 & 2.23 & 3.39 & & & & & \\
\hline Belgium & 0.17 & 15.5 & 0.3 & 0 & 5.5 & 8.2 & 33.0 & 1.96 & 34.7 \\
\hline France & 0.23 & 8.05 & 0.17 & 2 & 5.5 & 9.1 & 32.7 & 1.93 & 12.2 \\
\hline Greece & 0.07 & 21.6 & 0.3 & 1 & 5 & 10.2 & 34.3 & 1.95 & 13 \\
\hline Italy & 0.08 & 3.91 & 0.31 & 0 & 5.25 & 11.6 & 36.0 & 2.02 & 17.3 \\
\hline Netherlands & 0.52 & 21.13 & 0.66 & 2 & 5.5 & 9.2 & 30.9 & 2.11 & 36.7 \\
\hline Portugal & 0.08 & 19.5 & 0.5 & 2 & 5.5 & 15.0 & 38.5 & 2.08 & 21.3 \\
\hline Spain & 0.17 & 9.71 & 0.07 & 2 & 5.25 & 10.3 & 34.7 & 2.16 & 36 \\
\hline French origin avg & 0.19 & 14.2 & 0.33 & 1.29 & 5.36 & 10.5 & 34.3 & 2.03 & 24.5 \\
\hline La Porta et al. avg ${ }^{\mathrm{a}}$ & 0.21 & 10.00 & 0.19 & 1.76 & & & & & \\
\hline Austria & 0.06 & 13.87 & 0.25 & 2 & 5 & 6.9 & 29.1 & 2.02 & 32.2 \\
\hline Germany & 0.13 & 5.14 & 0.08 & 1 & 5 & 6.9 & 28.3 & 1.98 & 31.6 \\
\hline Japan & 0.62 & 17.78 & 0.26 & 3 & 4.5 & 4.5 & 24.9 & 1.79 & 9.4 \\
\hline Korea, Rep of & 0.44 & 15.88 & 0.02 & 2 & 5.25 & 7.8 & 31.6 & 1.99 & 13.4 \\
\hline Switzerland & 0.62 & 33.85 & - & 1 & 5.5 & 9.0 & 33.7 & 1.92 & 25 \\
\hline German origin avg & 0.37 & 17.3 & 0.15 & 1.8 & 5.05 & 7.0 & 29.5 & 1.94 & 22.3 \\
\hline La Porta et al. avg ${ }^{\mathrm{a}}$ & 0.46 & 16.79 & 0.12 & 2.00 & & & & & \\
\hline Denmark & 0.21 & 50.4 & 1.8 & 3 & 4.25 & 8.1 & 24.7 & 1.89 & 36.9 \\
\hline Finland & 0.25 & 13 & 0.6 & 2 & 4.75 & 5.6 & 26.9 & 1.88 & 42 \\
\hline Norway & 0.22 & 33 & 4.5 & 3 & 4 & 6.1 & 25.8 & 1.82 & 37.9 \\
\hline Sweden & 0.51 & 12.66 & 1.66 & 2 & 3.25 & 6.2 & 25.0 & 1.91 & 47.3 \\
\hline Scandinavian avg & 0.30 & 27.26 & 2.14 & 2.5 & 4.06 & 6.5 & 25.6 & 1.87 & 41.0 \\
\hline La Porta et al. avg ${ }^{\mathrm{a}}$ & 0.30 & 27.26 & 2.14 & 2.5 & & & & & \\
\hline
\end{tabular}

Definitions for each of the variables are given in Table 1

a Means reported for the original, and larger groups of countries reported in La Porta et al. (1997a)

The final social indicator, percentage of women MPs, is of a different type to the others but, as discussed above may be considered as a proxy for the progression of the democratic impulse and so could be construed as having features in common with the other measures. This indicator again shows, we would argue, the worst performance being found amongst the common law countries (in aggregate); although admittedly, there appears to be little difference between the three nonScandinavian groups. Close inspection reveals that the results are influenced by a few outliers. In the German group, the Asian nations have low figures which may be accounted for by differing cultural traditions. Were these to be removed, a rather different gradation of means would be apparent. However, the figures for France,
Greece and Ireland are all also relatively low. A cultural/ historical examination of possible explanations for these figures goes beyond the scope of this article. But we would venture that, prima facie, this evidence, taken together with that pertaining to income inequality, is consistent with the position advanced above by Reynolds regarding the distribution of power and influence in society.

The next part of this section presents a more rigorous statistical examination of the data in Table 2 (and the rest of the La Porta et al. data which appears in the Annex to this article) but it already appears that, compared to the civil law countries, the common-law tradition is associated with greater inequality and, possibly, with a relatively conservative approach to social development. 


\section{Statistical Analysis}

The empirical analysis in this section of the article has a number of parts. Initially, the social indicator variables (the under 5 child mortality rate, the two measures of income inequality-R10/P10 and the Gini index, the $\log$ of the prison population and \% women MPs) are examined for each of the legal-tradition categories which La Porta et al. derive. Specifically, the mean (median) of each of the social indicators is calculated for all four legal tradition groupings of countries and a test of the null hypothesis that the means (medians) were equal is conducted. The second empirical component of the current article examines the relationships that exist between the various proxies for investor protection which La Porta et al. employ when grouping countries and the social indicators examined in the current investigation. In particular, correlation analysis is used to study the sign and size of any relationships that may be present. The third empirical part of the analysis distils the information in the ten investor protection proxy variables, used by La Porta et al., into a number of principal components and regresses these components on the social indicators for the developed countries considered in the current study. In this way, a comprehensive investigation is undertaken to determine whether certain investor protection proxy variables and some legal tradition groupings of countries are associated with better indicators of social health and development such as under 5 child mortality, measures of income inequality, the size of the prison population or the representation of women among elected members of a country's parliament.

The initial investigation focused on whether the five social indicator variables being considered varied across the four groupings of countries from La Porta et al. based on legal traditions. The results from this analysis are shown in Table 3. The top half of this table reports the findings from an analysis of means while the bottom half documents the results for an investigation of the median values for each of the social indicator variables; the median analysis is reported because some of the descriptive statistics in Table 2 suggested that the variables might not be normally distributed. In the top half of the table, the mean value of each social indicator together with its standard deviation is provided for all four legal traditions. An $F$ statistic and its $p$ value are then reported for a test of the null hypothesis that these means were equal. In the bottom half of the article, median values and their associated $Z$ statistics are provided for each of the four groupings of countries and an $H$ statistic together with its $p$ value are shown for the null hypothesis that these median values were equal.

An analysis of Table 3 reveals that sizeable differences exist in the measures of social health across the four groupings of countries based on La Porta et al.'s classification scheme. In particular, the mean level of under 5 child mortality in countries where the legal tradition has an English common law origin (mean $=6.500$ ) is $60 \%$ higher than in Scandinavian countries $($ mean $=4.063)$. A similar picture emerges from the other four social indicator variables considered. Specifically, countries where the legal system is based on an English common law tend to have the greatest income inequality (according to both the R10/P10 and Gini index variables), the highest average prison populations and smallest percentage of women MPs. The Scandinavian countries perform best. In between, the countries where the legal tradition is based on French Law have the second highest (i.e. second worst) indicators across the first four variables, while those where the legal origin is German in character are ranked third. ${ }^{12}$ In some of the subsequent analysis, the four legal origins are labelled Legal Origin (LO) 1-4 according to their order in Table 3 and, for the purposes of the correlation analysis in Table 4, they are ranked in this order as the Legal Origin variable.

A more detailed inspection of Table 3 reveals that there is some variability within the country groupings for the social indicator variables being studied. In particular, some of the standard deviation figures were large. This seems to be especially the case for English common law countries where the standard deviation values were highest for three of the five social indicator variables being examined. For example, the standard deviation value of the log of prison population variable for English common law countries of 0.352 is nearly four times as large as the next highest standard deviation number. By contrast, Scandinavian countries tend to be much more homogenous in terms of the social indicator variables since the standard deviation values are smallest for four of the five measures being examined.

Despite this variability within groupings, the picture that emerges from Table 3 is that a very consistent pattern exists in terms of the rankings of the country groupings according to their social indicator variables. The $F$ statistics confirm that the mean values for each social indicator are not equal across the four country groupings. All of the $F$ statistics were large and statistically significant at the $10 \%$ levels; indeed, four of the $p$ values are less than the critical value of 0.05 . This finding is confirmed by an analysis of the median values and their corresponding

\footnotetext{
12 It should be noted that the ranking for the final social indicator variable (\% Women MPs) is the opposite to that for the other four where a high number is better than a low number; for the other four variables, a larger number indicates a higher level of child mortality, a greater level of income inequality and a greater prison population. In addition, this final indicator is the only one in which there is an exception to the otherwise consistent ranking order. This is the case for the French and German figures for \% Women MPs when ranked by mean, but the common pattern is completely consistent when the rankings are done by median, as shown in the lower panel of Table 3.
} 
Table 3 An analysis of the social indicator variables according to a country's legal origin

\begin{tabular}{|c|c|c|c|c|c|c|c|c|c|c|}
\hline \multirow[t]{2}{*}{ Legal origin } & \multicolumn{2}{|c|}{ U5MR 01-04 } & \multicolumn{2}{|c|}{ R10/P10 } & \multicolumn{2}{|c|}{ Gini index } & \multicolumn{2}{|c|}{ Log Pr Pop } & \multicolumn{2}{|c|}{$\%$ Women MPs } \\
\hline & Mean & StDev & Mean & StDev & Mean & StDev & Mean & StDev & Mean & StDev \\
\hline English & 6.500 & 0.775 & 12.250 & 2.534 & 35.850 & 2.758 & 2.203 & 0.352 & 21.167 & 6.664 \\
\hline French & 5.357 & 0.197 & 10.514 & 2.256 & 34.300 & 2.466 & 2.030 & 0.089 & 24.457 & 11.036 \\
\hline German & 5.050 & 0.371 & 7.020 & 1.651 & 29.520 & 3.347 & 1.939 & 0.090 & 22.320 & 10.457 \\
\hline Scandinavian & 4.063 & 0.625 & 6.500 & 1.098 & 25.600 & 0.983 & 1.874 & 0.040 & 41.025 & 4.730 \\
\hline$F$ statistic & 18.18 & & 9.28 & & 15.73 & & 2.72 & & 4.64 & \\
\hline$p$ value & 0.00 & & 0.01 & & 0.00 & & 0.08 & & 0.01 & \\
\hline \multirow[t]{2}{*}{ Legal origin } & \multicolumn{2}{|c|}{ U5MR 01-04 } & \multicolumn{2}{|l|}{$\mathrm{R} 10 / \mathrm{P} 10$} & \multicolumn{2}{|c|}{ Gini index } & \multicolumn{2}{|c|}{ Log Pr Pop } & \multicolumn{2}{|c|}{$\%$ Women MPs } \\
\hline & Median & $Z$ statistic & Median & $Z$ statistic & Median & $Z$ statistic & Median & $Z$ statistic & Median & $Z$ statistic \\
\hline English & 6.250 & 3.540 & 12.500 & 2.730 & 35.600 & 2.430 & 2.097 & 1.990 & 20.250 & -1.220 \\
\hline French & 5.500 & 0.180 & 10.200 & 1.450 & 34.300 & 1.450 & 2.017 & 1.020 & 21.300 & -0.530 \\
\hline German & 5.000 & -1.210 & 6.900 & -2.230 & 29.100 & -1.610 & 1.978 & -0.980 & 25.000 & -0.940 \\
\hline Scandinavian & 4.125 & -2.980 & 6.150 & -2.470 & 25.400 & -2.810 & 1.881 & -2.470 & 39.950 & 3.060 \\
\hline$H$ statistic & 17.86 & & 15.70 & & 14.19 & & 9.32 & & 9.64 & \\
\hline$p$ value & 0.00 & & 0.00 & & 0.00 & & 0.25 & & 0.02 & \\
\hline
\end{tabular}

$H$ statistics. With the exception of "\% Women MPs", the rankings of country groupings based on median values are identical to those based on their mean counterparts. Further, the null hypothesis that the medians are equal across the four country groupings can be rejected for four of the five social indicator variables; the exception to this general finding related to the $\log$ of prison population where the $H$ statistic is only 9.32 and its $p$ value is 0.25 .

The Spearman correlations ${ }^{13}$ (a) among the investor protection and legal origin variables and (b) between the investor protection as well as legal origin variables and the social indicator measures are displayed in Table 4. Based on the results from Table 2, and the ranking of the Legal Origin variable based on Table 3 , one would of course expect the correlation findings to confirm that a relationship exists between the legal origin of a country and its social indicators. However, this table goes further by examining whether a relationship exists between (i) the investor protection measures on which the legal origin grouping is based and (ii) the social indicator variables. Further, the table highlights whether there are correlations among the different investor protection measures which La Porta et al. employ or whether each one is capturing a

\footnotetext{
13 The non-parametric Spearman rank correlation analysis was selected because there was some evidence that the variables being examined were not normally distributed. In fact, descriptive statistics revealed that data for one of the social indicators and six of the investor protection variables were positively skewed. In addition, there was some evidence of kurtosis in the data series. However, an analysis of the parametric Pearson correlation coefficients revealed very little difference in the values calculated.
}

different aspect of the legal origin grouping used by La Porta et al.

A visual inspection of Table 4 reveals that there is a strong negative association between: under 5 child mortality; income inequality; as well as the size of prison population; and the legal origin measure used: of course these associations are to be expected given the construction of the legal origin variable. In addition, the association between the $\%$ of women MPs and legal origin is positive, consistent with the figures showing that Scandinavian countries have a much larger representation of female elected representatives in their Parliament relative to their common law counterparts. When the investor protection variables were examined, however, relatively few of the correlations were statistically significant; in fact only six correlation values have $p$ values of less than 0.05: Anti Dir and U5MR 01-04, FirmsPop and U5MR 01-04, GDP Growth and \% Women MPs, Log GNP and \% Women MPs, 1s1vote and \% Women MPs, Rule of Law and \% Women MPs. The remaining 44 correlations in the bottom panel of Table 4 are not statistically different from zero at the $5 \%$ level.

In the top half of Table 4, there is some evidence that the investor protection variables are correlated with one another. Of the 45 correlation values calculated, 12 were statistically significant: ExCapGNP and AntiDir, ExCapGNP and FirmsPop, ExCapGNP and IPOsPop, ExCapGNP and Debt/GNP, AntiDir and FirmsPop, AntiDir and IPOsPop, FirmsPop and IPOsPop, 1s1vote and IPOsPop, Debt/GNP and Log GNP, GDP Growth and 1s1vote, GDP Growth and Rule of Law, 1s1vote and Rule of Law. Such a 
Table 4 Correlation analysis

\begin{tabular}{|c|c|c|c|c|c|c|c|c|c|c|c|}
\hline & $\begin{array}{l}\text { Legal } \\
\text { origin }\end{array}$ & $\begin{array}{l}\text { ExCap/ } \\
\text { GNP }\end{array}$ & $\begin{array}{l}\text { AntiDir } \\
\text { rights }\end{array}$ & $\begin{array}{l}\text { Domestic } \\
\text { firms/Pop }\end{array}$ & $\begin{array}{l}\text { IPOs/ } \\
\text { Pop }\end{array}$ & CredR & $\begin{array}{l}\text { Debt/ } \\
\text { GNP }\end{array}$ & $\begin{array}{l}\text { GDP } \\
\text { growth }\end{array}$ & $\begin{array}{l}\text { Log } \\
\text { GNP }\end{array}$ & 1s1vote & $\begin{array}{l}\text { Rule } \\
\text { of law }\end{array}$ \\
\hline Legal origin & 1.000 & & & & & & & & & & \\
\hline ExCap/GNP & -0.1 .86 & 1.000 & & & & & & & & & \\
\hline AntiDir & $-0.423^{*}$ & $0.522 *$ & 1.000 & & & & & & & & \\
\hline Firms/Pop & $-0.364 *$ & $0.425^{*}$ & $0.671^{*}$ & 1.000 & & & & & & & \\
\hline IPOs/Pop & -0.222 & $0.413^{*}$ & $0.656^{*}$ & $0.688^{*}$ & 1.000 & & & & & & \\
\hline CredR & 0.238 & -0.030 & 0.016 & 0.004 & -0.126 & 1.000 & & & & & \\
\hline Debt/GNP & -0.168 & $0.481 *$ & 0.311 & -0.032 & -0.186 & 0.226 & 1.000 & & & & \\
\hline GDP growth & -0.148 & -0.129 & 0.162 & -0.164 & -0.214 & -0.139 & -0.011 & 1.000 & & & \\
\hline Log GNP & -0.125 & 0.336 & 0.040 & -0.307 & 0.181 & 0.050 & $0.557^{*}$ & 0.186 & 1.000 & & \\
\hline 1s1vote & 0.162 & 0.063 & -0.119 & -0.031 & $-0.413^{*}$ & 0.066 & -0.023 & 0.313 & 0.073 & 1.000 & \\
\hline Rule of law & 0.096 & 0.260 & 0.208 & 0.273 & $0.441^{*}$ & -0.096 & 0.216 & $-0.382 *$ & -0.056 & $-0.503 *$ & 1.000 \\
\hline U5MR 01-04 & $-0.912 *$ & 0.349 & $0.418^{*}$ & $0 . .416^{*}$ & 0.219 & -0.266 & 0.248 & 0.056 & 0.179 & -0.285 & 0.065 \\
\hline $\mathrm{R} 10 / \mathrm{P} 10$ & $-0.838^{*}$ & 0.036 & 0.293 & 0.350 & 0.206 & -0.204 & -0.003 & 0.009 & 0.035 & -0.240 & -0.207 \\
\hline Gini index & $-0.801^{*}$ & -0.007 & 0.146 & 0.199 & -0.029 & -0.243 & 0.037 & 0.044 & 0.006 & -0.188 & -0.200 \\
\hline Log Pr Pop & $-0.649^{*}$ & 0.049 & 0.248 & 0.199 & 0.019 & 0.130 & 0.336 & -0.027 & 0.214 & -0.261 & 0.088 \\
\hline$\%$ Women MPs & $0.484^{*}$ & -0.112 & -0.093 & 0.012 & 0.285 & 0.300 & -0.172 & $-0.417 *$ & $-0.368 *$ & $-0.533^{*}$ & $0.553 *$ \\
\hline
\end{tabular}

Note: This table shows the Spearman correlation coefficients for the variables included in the analysis. The top half of the table displays the correlation coefficients among the investor protection and legal origin variables while the bottom half of the table shows the correlation between the social indicators and the La Porta et al. variables. The Legal Origin variable reflects the ordinal ranking in Table 3. An explanation of the other variables is provided in Table 1 and in Supplement to Table 1b in Annex 1

* Indicates significance at the $1 \%$ level for a one-tail test

result is hardly surprising since many of the variables were constructed from a common component (e.g. GNP) while all were presumably selected by La Porta et al. because they helped to paint a picture about one issue (namely the protection of investor rights) within a country. All of these significant correlations had the expected signs. For example, it is not surprising that the correlation between ExCapGNP and Anti Dir is positive at 0.522 since one would expect the index value aggregating shareholders rights in a country to be high where the ratio of the capitalisation held by minority shareholders to GNP is high.

Since there is some evidence of a relationship among the investor protection variables from La Porta et al. studies, it was decided to use a statistical approach to take account of this correlation before examining the association between social indicators and the investor protection variables using regression analysis. ${ }^{14}$

To examine the possible relationship between indicators of social performance and the various investor protection variables in the La Porta et al. studies, Principal Components Analysis (PCA) was employed to identify relevant

\footnotetext{
${ }^{14}$ In fact, a regression of the social indicator variables on all of the investor protection measures and the legal origin dummy variables indicated that multicollinearity was present in the data. For example, when U5MR 01-04 was the dependent variable, five of the independent variables had variance inflation factors (VIFs) that were greater than 10. Thus, PCA was employed to overcome this problem.
}

factors from the pool of data under consideration. PCA is a method which significantly reduces the number of variables from $p$ to a much smaller set of $k$ derived orthogonal variables that retain most of the information in the original $p$ variables. The $k$ derived variables which maximise the variance accounted for in the original variables are called principal components (PCs). After applying this analysis to the data series of each of the developed countries being studied, the dominant PCs are then extracted and used as inputs into a regression analysis to seek to explain the social indicators included in the study. The use of PCA is appealing for a number of reasons. First, it allows a large number of theoretically important factors that may affect the social indicators to be considered and second, it can be used effectively in conjunction with multiple regression analysis by addressing the problems of multicollinearity; specifically, because the $k$ derived variables are orthogonal to each other, multicollinearity should not be present.

Table 5 summarises the results from applying PCA to the investor protection variables considered in the La Porta et al. papers. In particular, the bottom part of Table 5 details the eigenvalues and proportions of variance explained by the PCs, while the top part of Table 5 summarises the factor loadings for the dominant PCs. The data in Table 5 clearly show that across all 22 countries examined, the bulk of the variability in the original ten investor protection variables can be explained by 4 PCs. 
For example, the variance, or eigenvalue, of the first PC is 3.027. It explains $30.3 \%$ of the total variance of the ten investor protection variables. The second $\mathrm{PC}$ has an eigenvalue of 2.291 and accounts for $22.9 \%$ of total variance of the 10 variables. The third and fourth PCs also have eigenvalues greater than 1 and account for 17.0 and $11.3 \%$, respectively, of the variability in the investor protection measures across the different countries. The proportion of variance explained by the remaining six PCs is relatively low and their eigenvalues are all small.

The Kaiser criterion was used to select the PCs which should be used as inputs for the regression analysis. The criterion recommends that only those PCs with eigenvalues greater than or equal to 1 , should be retained (Kaiser 1960). Jolliffe (1972) has suggested a cut-off point of 0.7. However, in this instance, Jolliffe's criterion results in the same number of components being retained as Kaiser's criterion of the eigenvalue being greater than or equal to 1 (Dunteman 1994). Therefore, the adoption of these criteria led to the retention of four PCs, which we describe in more detail below. Together, these four PCs account for $81.5 \%$ of the variance in the investor protection variables. Therefore, the dimensionality of the dataset can be reduced from 10 to 4 .

The values in the top half of Table 5 indicate the factor loadings of the PCs that are identified from the data. In particular, the top half of the table therefore highlights the variables that have large coefficients of either sign in each PC vector. ${ }^{15}$ The first PC, which is shown in column 2, has high positive correlations with AntiDir, Rule of Law and IPOsPop and negative correlations with GDP Growth as well as 1s1vote. This PC primarily reflects strong shareholder rights and a vibrant new issue market; we have labelled it "Outsider Capitalism" in the current analysis. The second PC shows large negative co-efficients for ExCapGNP, GDP Growth and 1s1vote and can be interpreted as small stock market/low growth variable. We label this PC "Insider Capitalism" in the remainder of the article. The largest co-efficients for the third PC are positive for FirmsPop and negative for GDP Growth as well as Debt/ GNP. This can be interpreted as a large stock market/low

\footnotetext{
15 PCA is subject to a number of limitations. One limitation of the method is that it can often be difficult to interpret the principal components. This situation typically arises when several variables in the PC vectors have large coefficients of either sign (Dunteman 1994). However, this limitation was not a concern in the current analysis as, for each variable, the identity of the high loading variables in each PC vector was very clear. A second limitation of the technique is that the choice of how many PCs to extract for further analysis is subjective; although the PCs will explain most of the variation in the original factors, they may not be useful in explaining the dependent variable (Brooks 2002). That is, and in terms of the current analysis, although the PCs will explain most of the variation in the original investor protection factors, they may not be the most useful at explaining the relationships between investor protection and social indicator variables.
}

growth/low debt variable; as a result, we label this PC as the "Small Economy" variable. The fourth PC is mainly associated with strong "Creditor Rights".

In the final part of the empirical analysis, the dominant PCs together with legal origin dummy variables are used as inputs to a regression analysis in order to explain the social indicator variables of the 22 developed countries included in this study. ${ }^{16}$ Five regression models are considered. First, the under 5 child mortality figures of the sample countries are regressed on each of the four PCs as well as three dummy variables representing legal origin (LO2 (French), LO3 (German) and LO4 (Scandinavian)); a variable was not added for LO1 (English) as the regression equation would have been over-specified. Instead, the impact of Legal Origin 1 is accounted for in the constant term: all of the other co-efficients need to be interpreted relative to the level of under 5 child mortality rate (U5MR 01-04) in English common law countries. ${ }^{17}$ Four similar regression equations were estimated for the other social indicator variables. These regression models took the form:

$$
\begin{aligned}
\text { SIsi }= & \beta_{0}+\beta_{1} \mathrm{PC}_{1 \mathrm{i}}+\beta_{2} \mathrm{PC}_{2 \mathrm{i}}+\beta_{3} \mathrm{PC}_{3 \mathrm{i}}+\beta_{4} \mathrm{PC}_{4 \mathrm{i}} \\
& +\beta_{5} \mathrm{LO} 2+\beta_{6} \mathrm{LO} 3+\beta_{7} \mathrm{LO} 4+\varepsilon_{\mathrm{i}}
\end{aligned}
$$

where SIsi is the social indicator $s$ for country $i$ ( $\mathrm{s}=$ U5MR 01-04, R10/P10, Gini index, Log Pr Pop and $\%$ Women MPs), $\mathrm{PC}_{\mathrm{i}}$ is principal component for country $\mathrm{i}$, LO is the Legal Origin dummy variable for French (LO2), German (LO3) and Scandinavian (LO4) legal traditions. Finally, $\varepsilon_{\mathrm{i}}$ is a random error term.

Table 6 reports the results from estimating Eq. $1 .{ }^{18}$ In particular, the table details the co-efficient of each PC and Legal Origin dummy variable, with their corresponding $p$ values. The adjusted $R^{2}$ s for the five regressions are also shown. An inspection of Table 6 suggests that a significant relationship exists between some of the social indicator measures and the PC as well as a number of the legal origin dummy variables. The strongest and most significant associations are between under 5 child mortality as well as

\footnotetext{
${ }^{16}$ In fact, the regression results reported in this paper relate to data for 20 of the 22 countries since IPOsPop information was missing for Australia and Switzerland. However, imputing values for these two missing observations and thereby increasing the sample up to 22 countries does not alter either the PCA results or the regression findings.

17 A regression was also run where one dummy variable was added depending on whether the country had an English common law tradition (value $=1$ ), or not (value $=0$ ). In this instance, the dummy variable had the following co-efficients: $2.237(p=0.000)$ for under 5 child mortality; $5.124(p=0.038)$ for R10/P10; 10.498 $(p=0.003)$ for the Gini index; $0.256(p=0.142)$ for Log Pr Pop; and $-16.143(p=0.013)$ for $\%$ Women MPs.

18 Although not shown in Table 6, the VIFs for all of the variables were less than 5.0 suggesting that multicollinearity was not a problem in these regression equations.
} 
Table 5 A principal component analysis of the La Porta et al. investor protection variables

\begin{tabular}{lrrrrrrrrrr}
\hline Variable & pc1 & \multicolumn{1}{c}{$\mathrm{pc} 2$} & \multicolumn{1}{c}{$\mathrm{pc3}$} & \multicolumn{1}{c}{$\mathrm{pc} 4$} & \multicolumn{1}{c}{$\mathrm{pc5}$} & $\mathrm{pc6}$ & $\mathrm{pc7}$ & $\mathrm{pc8}$ & $\mathrm{pc9}$ & $\mathrm{pc10}$ \\
\hline ExCap/GNP & 0.326 & -0.438 & 0.002 & -0.012 & -0.034 & 0.272 & 0.715 & 0.228 & -0.112 & -0.225 \\
AntiDir & 0.454 & -0.184 & 0.283 & -0.187 & -0.223 & -0.230 & 0.044 & -0.339 & -0.122 & 0.641 \\
Firms/Pop & 0.369 & 0.051 & 0.489 & 0.217 & -0.284 & 0.045 & -0.320 & -0.166 & -0.164 & -0.579 \\
IPOs/Pop & 0.401 & 0.065 & 0.246 & -0.402 & 0.525 & 0.147 & -0.194 & 0.247 & 0.466 & -0.023 \\
CredR & 0.104 & -0.229 & 0.077 & 0.792 & 0.440 & 0.148 & -0.123 & -0.005 & 0.007 & 0.271 \\
Debt/GNP & 0.233 & -0.391 & -0.401 & 0.152 & -0.282 & -0.451 & -0.189 & 0.127 & 0.504 & -0.140 \\
GDP Growth & -0.257 & -0.409 & 0.274 & -0.158 & 0.389 & -0.593 & -0.040 & 0.119 & -0.342 & -0.179 \\
Log GNP & 0.118 & -0.377 & -0.469 & -0.265 & 0.194 & 0.339 & -0.361 & -0.412 & -0.294 & -0.121 \\
1s1vote & -0.288 & -0.409 & 0.249 & -0.104 & -0.362 & 0.372 & -0.362 & 0.474 & -0.016 & 0.227 \\
Rule of Law & 0.403 & 0.292 & -0.311 & 0.032 & -0.002 & -0.136 & -0.180 & 0.566 & -0.521 & 0.107 \\
Eigenvalue & 3.027 & 2.291 & 1.696 & 1.132 & 0.546 & 0.447 & 0.359 & 0.283 & 0.130 & 0.090 \\
Proportion & 0.303 & 0.229 & 0.170 & 0.113 & 0.055 & 0.045 & 0.036 & 0.028 & 0.013 & 0.009 \\
Cumulative & 0.303 & 0.532 & 0.701 & 0.815 & 0.869 & 0.914 & 0.950 & 0.978 & 0.991 & 1.000 \\
\hline
\end{tabular}

Note: This table shows the output from applying a principal component analysis to the investor protection variables in the La Porta et al. study. The top part of the table shows the weightings for the ten investor protection variables of each PC. The bottom part of the table highlights the importance of each PC in explaining the investor protection variables. An explanation of the variables is provided in Table 1 and in Supplement to Table $1 \mathrm{~b}$ in Annex 1

income inequality and legal origin variables. For example, the co-efficients for the legal origin variables are negative for the U5MR 01-04 equation suggesting that under 5 child mortality is lower in countries which do not have an English common law tradition; for those countries with a German or Scandinavian legal tradition, the co-efficients on the U5MR 01-04 variable are statistically significant at the 5\% level. A similar picture emerges for the Gini index equation where Legal Origin 3 and Legal Origin 4 dummy variables have co-efficients of -9.068 and -10.810 with $p$ values of 0.020 and 0.000 , respectively. For the R10/P10 (\% Women MPs) variables, only the co-efficient for the Legal Origin 4 countries is significantly negative (positive) at the $5 \%$ level.

An inspection of the co-efficients on the PC variables indicates that only one significant value is observed. The Creditor Rights variable (PC4) is positively associated with the percentage of women MPs in a country (co-efficient $=4.244, p$ value $=0.025$ ). However, this may simply reflect the fact that in Scandinavian countries, creditor rights are protected to a greater extent and a larger percentage of MPs are women. None of the other PC measures constructed from the investor protection variables employed in La Porta et al. can significantly explain the social indicators of the countries being studied.

Finally, it is worth pointing out that three of the regression equations have relatively high explanatory power. Specifically, for the U5MR 01-04, Gini index and $\%$ Women MPs, the $R^{2}$ values are $0.71,0.65$ and 0.63 , respectively. The only equation with a very low level of explanatory power is where Log Pr Pop is the dependent variable; in this instance, the $R^{2}$ is only 0.05 and none of the co-efficient values are statistically different from zero.

\section{Common and Civil Law Traditions, Corporate Law and Concluding Comments}

In assessing the impact of their own work, particularly in the context of Berle and Means' seminal identification of the agency issue, La Porta et al. (2008) state that:

The last decade has witnessed an explosion of research on corporate governance that uses the investor protection framework. This research has successfully replaced the traditional Berle-Means conception of a public corporation with a much more realistic for most of the world model of family-run firms, pyramidal and group structures, and tremendous conflicts between outside investors and controlling shareholders. (p. 287)

However, La Porta et al. appear to be silent on Berle and Means' explicit critique of the common law tradition, and its implications for their own assessment of the distinction between corporate governance regimes under common and civil legal traditions. More specifically, Berle and Means reason that the nature of the modern corporation "calls for analysis, not in terms of business enterprise but in terms of social organization" because the corporation has become a site of highly centralized power in which many interests are at stake. Their discussion then centres on the historical process by which power is challenged-as happened in 
Table 6 Regression results

\begin{tabular}{|c|c|c|c|c|c|c|c|c|c|c|}
\hline \multirow[t]{2}{*}{ Predictor } & \multicolumn{2}{|c|}{ U5MR 01-04 } & \multicolumn{2}{|l|}{$\mathrm{R} 10 / \mathrm{P} 10$} & \multicolumn{2}{|c|}{ Gini index } & \multicolumn{2}{|c|}{ Log Pr Pop } & \multicolumn{2}{|c|}{$\%$ Women MPs } \\
\hline & $\beta$ & $p$ value & $\beta$ & $p$ value & $\beta$ & $p$ value & $\beta$ & $p$ value & $\beta$ & $p$ value \\
\hline Constant & 6.468 & 0.000 & 11.608 & 0.000 & 36.869 & 0.000 & 2.134 & 0.000 & 19.319 & 0.002 \\
\hline PC1 & 0.069 & 0.606 & 0.235 & 0.683 & -0.494 & 0.470 & 0.0489 & 0.375 & 1.964 & 0.268 \\
\hline $\mathrm{PC} 2$ & -0.027 & 0.818 & -0.256 & 0.611 & -0.115 & 0.846 & -0.009 & 0.845 & 2.508 & 0.114 \\
\hline PC3 & -0.049 & 0.710 & 0.209 & 0.715 & -0.024 & 0.971 & -0.010 & 0.858 & -1.713 & 0.498 \\
\hline $\mathrm{PC} 4$ & -0.154 & 0.252 & 0.277 & 0.623 & -0.008 & 0.991 & -0.020 & 0.704 & 4.244 & 0.025 \\
\hline LO2 & -1.065 & 0.092 & -0.533 & 0.835 & -3.083 & 0.317 & -0.051 & 0.835 & 6.015 & 0.440 \\
\hline LO3 & -1.452 & 0.049 & -5.335 & 0.087 & -9.068 & 0.020 & -0.152 & 0.585 & 5.670 & 0.522 \\
\hline LO4 & -2.397 & 0.000 & -5.100 & 0.016 & -10.81 & 0.000 & -0.278 & 0.134 & 18.261 & 0.006 \\
\hline$R^{2}$ & 0.71 & & 0.43 & & 0.65 & & 0.05 & & 0.63 & \\
\hline
\end{tabular}

Note: This table displays the coefficients $(\beta \mathrm{s})$ and their $p$ values for the five regressions undertaken. PC1 to PC4 represent the PCs extracted from the investor protection variables while LO2, LO3 and LO4 are dummy variables representing the French, German and Scandinavian legal origins, respectively. LO1 (English common law) was not included in order to avoid over-specifying the equation. $R^{2}$ refers to the adjusted $R^{2}$ of the regression equation

relation to the absolute religious power once wielded by the church, and the slow process by which constitutional law developed in the political context. Berle and Means do not predict how the diverse groups which have an interest in the operation of the corporation will resolve their interests; but they do take a normative, as well as an analytic, perspective in considering future possibilities.

They base their suggestion that courts mediate among competing organisational interests to serve society, on a continuing historical process whereby concentrated power is forced to accede to the wider interests of the polity (see also Engelen 2002 and Gomez and Korine 2005). They argue that:

It is conceivable, - indeed it seems almost essential if the corporate system is to survive, - that the "control" of the great corporations should develop into a purely neutral technocracy, balancing a variety of claims by various groups in the community and assigning to each a portion of the income stream on the basis of public policy rather than private cupidity. (p. 313) ${ }^{19}$

They go on to reiterate the point about the historical imperative whereby power is and should be challenged whenever it becomes too concentrated-and with great prescience they foresee the potential for corporations to become so powerful that they can dominate the state. This reinforces their central point that the control of such organisations should become a matter of constitutional reform in the wider democratic and public interest, rather than a vehicle for promoting the interest of powerful groups.

Their views of the differing characteristics of a legal framework which aims to balance the interests of all

\footnotetext{
${ }^{19}$ For a vigorous and well known challenge to such a governance philosophy, see Jensen (2001).
}

members of society, and the common law which merely seeks to defend "men in their own" are, we submit, of great salience given the evidence adduced in this article of the wider societal impacts which are associated with different legal traditions. It clearly leads to the conjecture that civil law countries have achieved a better balancing of claims by different "groups in the community" such that their societies have lower levels of income inequality and therefore of the social ills that are increasingly (and measurably) recognised as its consequence.

We acknowledge that the lens provided by La Porta et al. on the relationship between varieties of capitalism, including legal traditions and related forms of corporate governance, has been insightful. However, we would argue that their restricted set of criteria for assessing prosperity has obscured very important implications of aspects of their work for wider society. In particular, their claims regarding the relative superiority of the common law approach to the "social control of economic life" are very clearly contestable.

Our conclusion to this article can be stated succinctly. Following the thrust of the Berle and Means' analysis we contend that the common law tradition is associated with the spurious depoliticisation of issues that are central to political mediation. And we have adduced evidence that the AngloAmerican common law tradition leads to social outcomes, relative to those found in countries with a civil law tradition, which should give cause for profound disquiet and prompt the question of how such outcomes could be ameliorated. It is in this context, we believe, that the wide influence of the work of La Porta et al. is a matter for concern.

Acknowledgments The authors are very grateful to Dick Brown for advice regarding the statistical analysis. We would also like to thank Patricia Arnold, Jesse Dillard, Jill Solomon and anonymous referees 
for their helpful comments on the article. In addition, we would like to thank participants at: the 2010 North American and UK Conferences of the Centre for Social and Environmental Accounting Research held, respectively, in Orlando and St Andrews; and the 2010 British Accounting Association National Conference held in Cardiff.

\section{Annex 1: Table supplements}

Supplement to Table 1b: Description of the variables

\begin{tabular}{|c|c|}
\hline CredR & $\begin{array}{l}\text { An index aggregating creditor rights. The index is } \\
\text { formed by adding } 1 \text { when: (1) the country imposes } \\
\text { restrictions, such as creditors' consent or minimum } \\
\text { dividends, to file for reorganization; ( } 2 \text { ) secured } \\
\text { creditors are able to gain possession of their security } \\
\text { once the reorganization petition has been approved (no } \\
\text { automatic stay); (3) the debtor does not retain the } \\
\text { administration of its property pending the resolution of } \\
\text { the reorganization; (4) secured creditors are ranked } \\
\text { first in the distribution of the proceeds that result from } \\
\text { the disposition of the assets of a bankrupt firm. The } \\
\text { index ranges from } 0 \text { to } 4 \text {. }\end{array}$ \\
\hline Debt/GNP & $\begin{array}{l}\text { Ratio of the sum of bank debt of the private sector and } \\
\text { outstanding non-financial bonds to GNP in 1994, or } \\
\text { last available. }\end{array}$ \\
\hline $\begin{array}{l}\text { GDP } \\
\text { Growth }\end{array}$ & $\begin{array}{l}\text { Average annual percent growth of per capita gross } \\
\text { domestic product for the period 1970-1993. }\end{array}$ \\
\hline Log GNP & Logarithm of Gross National Product in 1994. \\
\hline 1s1vote & $\begin{array}{l}\text { Equals one if the Company Law or Commercial Code of } \\
\text { the country requires that ordinary shares carry one vote } \\
\text { per share, and } 0 \text { otherwise. Equivalently, this variable } \\
\text { equals one when the law prohibits the existence of } \\
\text { both multiple-voting and non-voting ordinary shares } \\
\text { and does not allow firms to set a maximum number of } \\
\text { votes per shareholder irrespective of the number of } \\
\text { shares she owns, and } 0 \text { otherwise. }\end{array}$ \\
\hline $\begin{array}{l}\text { Rule of } \\
\text { Law }\end{array}$ & $\begin{array}{l}\text { Assessment of the law and order tradition in the country } \\
\text { Average of the months of April and October of the } \\
\text { monthly index between } 1982 \text { and } 1995 \text {. Scale from } 0 \\
\text { to } 10 \text {, with lower scores for less tradition for law and } \\
\text { order. }\end{array}$ \\
\hline
\end{tabular}

Supplement to Table 2

\begin{tabular}{llllllr}
\hline Country & CredR & $\begin{array}{l}\text { Debt/ } \\
\text { GNP }\end{array}$ & $\begin{array}{l}\text { GDP } \\
\text { G'th }\end{array}$ & $\begin{array}{l}\text { Log } \\
\text { GNP }\end{array}$ & $\begin{array}{l}\text { 1s } \\
\text { 1vote }\end{array}$ & $\begin{array}{l}\text { Rule of } \\
\text { Law }\end{array}$ \\
\hline Australia & 1 & 0.76 & 3.06 & 12.64 & 0 & 10.00 \\
Canada & 1 & 0.72 & 3.36 & 13.26 & 0 & 10.00 \\
Ireland & 1 & 0.38 & 4.25 & 10.73 & 0 & 7.80 \\
New & 3 & 0.90 & 1.67 & 10.69 & 0 & 10.00 \\
$\quad$ Zealand & & & & & & \\
UK & 4 & 1.13 & 2.27 & 13.86 & 0 & 8.57 \\
USA & 1 & 0.81 & 2.74 & 15.67 & 0 & 10.00 \\
English & $\mathbf{1 . 8 3}$ & $\mathbf{0 . 7 8}$ & $\mathbf{2 . 8 9}$ & $\mathbf{1 2 . 8 1}$ & $\mathbf{0 . 0 0}$ & $\mathbf{9 . 4 0}$ \\
$\quad$ origin avg & & & & & & \\
\hline
\end{tabular}

\begin{tabular}{|c|c|c|c|c|c|c|}
\hline Country & CredR & $\begin{array}{l}\text { Debt/ } \\
\text { GNP }\end{array}$ & $\begin{array}{l}\text { GDP } \\
\text { G'th }\end{array}$ & $\begin{array}{l}\text { Log } \\
\text { GNP }\end{array}$ & $\begin{array}{l}\text { 1s } \\
1 \text { vote }\end{array}$ & $\begin{array}{l}\text { Rule of } \\
\text { Law }\end{array}$ \\
\hline $\begin{array}{l}\text { La Porta et al. } \\
\text { avg }\end{array}$ & 3.11 & 0.68 & 4.30 & 11.41 & 0.22 & 6.46 \\
\hline Belgium & 2 & 0.38 & 2.46 & 12.29 & 0 & 10.00 \\
\hline France & 0 & 0.96 & 2.54 & 14.07 & 0 & 8.98 \\
\hline Greece & 1 & 0.23 & 2.46 & 11.25 & 1 & 6.18 \\
\hline Italy & 2 & 0.55 & 2.82 & 13.94 & 0 & 8.33 \\
\hline Netherlands & 2 & 1.08 & 2.55 & 12.68 & 0 & 10.00 \\
\hline Portugal & 1 & 0.64 & 3.52 & 11.41 & 0 & 8.68 \\
\hline Spain & 2 & 0.75 & 3.27 & 13.19 & 0 & 7.80 \\
\hline $\begin{array}{l}\text { French origin } \\
\text { avg }\end{array}$ & 1.43 & 0.66 & 2.80 & 12.69 & 0.14 & 8.57 \\
\hline $\begin{array}{l}\text { La Porta et al. } \\
\text { avg }\end{array}$ & 1.58 & 0.45 & 3.18 & 11.55 & 0.24 & 6.05 \\
\hline Austria & 3 & 0.79 & 2.74 & 12.13 & 0 & 10.00 \\
\hline Germany & 3 & 1.12 & 2.60 & 14.46 & 0 & 9.23 \\
\hline Japan & 2 & 1.22 & 4.13 & 15.18 & 1 & 8.98 \\
\hline Korea, South & 3 & 0.74 & 9.52 & 12.73 & 1 & 5.35 \\
\hline Switzerland & 1 & - & 1.18 & 12.44 & 0 & 10.00 \\
\hline $\begin{array}{l}\text { German } \\
\text { origin avg }\end{array}$ & 2.40 & 0.97 & 4.03 & 13.39 & 0.4 & 8.71 \\
\hline $\begin{array}{l}\text { La Porta et al. } \\
\text { avg }\end{array}$ & 2.33 & 0.97 & 5.29 & 13.21 & 0.33 & 8.68 \\
\hline Denmark & 3 & 0.34 & 2.09 & 11.84 & 0 & 10.00 \\
\hline Finland & 1 & 0.75 & 2.40 & 11.49 & 0 & 10.00 \\
\hline Norway & 2 & 0.64 & 3.43 & 11.62 & 0 & 10.00 \\
\hline Sweden & 2 & 0.55 & 1.79 & 12.28 & 0 & 10.00 \\
\hline $\begin{array}{c}\text { Scandinavian } \\
\text { origin avg }\end{array}$ & 2.00 & 0.57 & 2.43 & 11.81 & 0.00 & 10.00 \\
\hline $\begin{array}{l}\text { La Porta et al. } \\
\text { avg }\end{array}$ & 2.00 & 0.57 & 2.42 & 11.80 & 0.00 & 10.00 \\
\hline
\end{tabular}

Definitions for each of the variables are given in Supplement to Table 1b

Adapted and developed from La Porta et al. (1997a, p. 1138, Table II)

\section{References}

Aguilera, R. V., \& Jackson, G. (2003). The cross-national diversity of corporate governance: Dimensions and determinants. Academy of Management Review, 28(3), 447-465.

Ahlering, B., \& Deakin, S. (2007). Labor regulation, corporate governance, and legal origin: A case of institutional complementarity? Law \& Society Review, 41(4), 865-908.

Armour, J., Deakin, S., Mollica, V., \& Siems, M. (2010). Law and financial development: What we are learning from time-series evidence. Cambridge: Centre for Business Research, University Of Cambridge.

ASSC (Accounting Standards Steering Committee). (1975). The Corporate Report ICAEW, London.

Bauer, R. A. (Ed.). (2006). Social indicators. Cambridge and London: MIT Press.

Berle, A. A., \& Means, G. C. (1967/1932). The modern corporation and private property. New York: Harcourt, Brace \& World Inc. 
Braendle, U. C. (2006). Shareholder protection in the USA and Germany-'Law and Finance' revisited. German Law Journal, 7(3), 257-278.

Brooks, C. (2002). Introductory econometrics for finance. Cambridge: Cambridge University Press.

Burchell, S., Clubb, C., \& Hopwood, A. (1985). Accounting in its social context: Towards a history of value added in the United Kingdom. Accounting Organizations and Society, 10(4), $381-413$.

Carley, M. (1981). Social measurement and social indicators. Issues of policy and theory. London: George Allen and Unwin.

Chih, H., Chih, H., \& Chen, T. (2010). On the determinants of corporate social responsibility: International evidence on the financial industry. Journal of Business Ethics, 93, 115-135.

Christian, D. (1974). International social indicators: The OECD experience. Social Indicators Research, 1, 169-186.

Chui, A. C. W., Lloyd, A. E., \& Kwok, C. C. Y. (2002). The determination of capital structure: is national culture a missing piece to the puzzle? Journal of International Business Studies, $33(1), 99-127$.

Collison, D. J. (2003). Corporate propaganda: Its implications for accounting and accountability. Accounting Auditing and Accountability Journal, 16(5), 853-886.

Collison, D. J., Dey, C. R., Hannah, G., \& Stevenson, L. A. (2007). Income inequality and child mortality in wealthy nations. Journal of Public Health, 29(2), 114-117.

Collison, D. J., Dey, C. R., Hannah, G., \& Stevenson, L. A. (2010). Anglo-American capitalism: The role and potential role of social accounting. Accounting Auditing and Accountability Journal, 23(8), 956-981.

Day, R., \& Woodward, T. (2004). Disclosure of information about employees in the Directors' report of UK published financial statements: substantive or symbolic? Accounting Forum, 28(1), 43-59.

Diener, E., \& Suh, E. (1997). Measuring quality of life: Economic, social and subjective indicators. Social Indicators Research, 40, 189-216.

Dignam, A., \& Galanis, M. (2008). Corporate governance and the importance of macroeconomic context. Oxford Journal of Legal Studies, 28(2), 201-243.

Dore, R. (1999). Varieties of capitalism in the twentieth century. Oxford Review of Economic Policy, 15(4), 102-120.

Dore, R. (2000). Stock market capitalism: Welfare capitalism. New York: Oxford University Press.

Dore, R. (2006, Dec 22-24). Japan's shareholder revolution. CentrePiece Magazine, Paper No. CEPCP220.

Dunteman, G. H. (1994). Principal components analysis. In M. S. Lewis-Beck (Ed.), Factor analysis and related techniques, international handbook of quantitative applications in the social sciences (Vol. 5). London: Sage Publications.

Engelen, E. (2002). Corporate governance, property and democracy: A conceptual critique of shareholder ideology. Economy and Society, 31(3), 391-413.

Galnoor, I. (1974). Social indicators for social planning: The case of Israel. Social Indicators Research, 1, 27-57.

Glaeser, E. L., La Porta, R., Lopez-de-Silanes, F., \& Schleifer, A. (2004). Do institutions cause growth? Journal of Economic Growth, 9(3), 371-372.

Glatzer, W. (1981). An overview of the international development in macro social indicators. Accounting, Organizations and Society, 6(3), 219-234.

Goeke, J. (1974). Some neglected social indicators. Social Indicators Research, 1, 85-105.

Gomez, P., \& Korine, H. (2005). Democracy and the evolution of corporate governance. Corporate Governance, 13(6), 739-752.
Gray, R. H., Kouhy, R., \& Lavers, S. (1995). Corporate social and environmental reporting: A review of the literature and a longitudinal study of UK disclosure. Accounting Auditing and Accountability Journal, 8(2), 47-77.

Hall, P. A., \& Soskice, D. (2001). Varieties of capitalism: The institutional foundations of comparative advantage. New York: Oxford University Press.

Hansmann, H., \& Kraakman, R. (2001). The end of history for corporate law. The George Town Law Journal, 89, 439-468.

Hutton, W. (1995). The state we're in. London: Jonathan Cape.

Hutton, W. (2003). The world we're in. London: Abacus.

Ireland, P. (2001). Defending the rentier: Corporate theory and the reprivatization of the public company. In J. Parkinson, A. Gamble, \& G. Kelly (Eds.), The Political Economy of the Company (pp. 141-173). Oxford: Hart.

Jackson, G., \& Apostolakou, A. (2010). Corporate social responsibility in Western Europe: An institutional mirror or substitute? Journal of Business Ethics, 94, 371-394.

Jensen, M. (2001). Value maximization, stakeholder theory, and the corporate objective function. Journal of European Financial Management, 298-317.

Jensen, M. C., \& Meckling, W. H. (1976). Theory of the firm: Managerial behavior agency costs and ownership structure. Journal of Financial Economics, 3(4), 305-360.

Jolliffe, I. T. (1972). Discarding variables in a principal components analysis I: Artificial data. Applied Statistics, 21(2), 160-173.

Kaiser, H. F. (1960). The application of electronic computers to factor analysis. Educational and Psychological Measurement, 20(1), 141-151.

Keloharju, M. (2008). What's new in finance? European Financial Management, 14(3), 564-608.

Keynes, J. M. (1936/2008). The general theory of employment, interest and money. Macmillan Cambridge University Press, for Royal Economic Society in 1936 republished by BN Publishing.

King, R. G., \& Levine, R. (1993). Finance and growth: Schumpeter might be right. Quarterly Journal of Economics, 108, 717-737.

Kohn, M. (2001, Oct). Evolutionary left. Prospect Magazine, pp. $40-43$.

La Porta, R., Lopez-de-Silanes, F., \& Shleifer, A. (1999a). The quality of government. The Journal of Law Economics and Organization, 15(1), 222-279.

La Porta, R., Lopez-de-Silanes, F., \& Shleifer, A. (1999b). Corporate ownership around the world. Journal of Finance, 54(2), 471-517.

La Porta, R., Lopez-de-Silanes, F., \& Shleifer, A. (2006). What works in securities laws? The Journal of Finance, 61(1), 1-32.

La Porta, R., Lopez-de-Silanes, F., \& Shleifer, A. (2008). The economic consequences of legal origins. Journal of Economic Literature, 46(2), 285-286.

La Porta, R., Lopez-de-Silanes, F., Shleifer, A., \& Vishny, R. W. (1996). Law and Finance, NBER Working Paper No. 5661.

La Porta, R., Lopez-de-Silanes, F., Shleifer, A., \& Vishny, R. W. (1997a). Legal determinants of external finance. The Journal of Finance, 52(3), 1131-1150.

La Porta, R., Lopez-de-Silanes, F., Shleifer, A., \& Vishny, R. W. (1997b). Trust in large organisations. American Economic Review Paper and Proceedings, 87, 333-338.

La Porta, R., Lopez-de-Silanes, F., Shleifer, A., \& Vishny, R. W. (1998). Law and finance. Journal of Political Economy, 106(6), 1113-1155.

La Porta, R., Lopez-de-Silanes, F., Shleifer, A., \& Vishny, R. W. (2000a). Investor protection and corporate governance. Journal of Financial Economics, 58(1), 3-27.

La Porta, R., Lopez-de-Silanes, F., Shleifer, A., \& Vishny, R. W. (2000b). Agency problems and dividend policies around the world. Journal of Finance, 55(1), 1-33. 
La Porta, R., Lopez-de-Silanes, F., Shleifer, A., \& Vishny, R. W. (2002). Investor protection and corporate valuation. The Journal of Finance, 57(3), 1147-1170.

Layard, R. (2005). Happiness: Lessons from a new science. New York: Penguin.

Levine, R. (1998). The legal environment, banks and long-run economic growth. Journal of Money Credit and Banking, 30(3), $596-613$.

Levine, R., \& Zervos, S. (1998). Stock markets, banks, and economic growth. American Economic Review, 88(3), 537-558.

Liu, B. (1974). Quality of life indicators: A preliminary investigation. Social Indicators Research, 1, 187-208.

Macintosh, J. C. C. (1999). The issues, effects and consequences of the Berle-Dodd debate, 1931-1932. Accounting Organizations and Society, 24(1), 139-153.

Matten, D., \& Moon, J. (2008). "Implicit" and "Explicit" CSR: A conceptual framework for a comparative understanding of corporate social responsibility. Academy of Management Review, 33(2), 404-424.

Milhaupt, C. J. (2005). In the shadow of Delaware? The rise of hostile takeovers in Japan. Columbia Law Review, 105(7), 2171-2216.

OECD. (1976). Measuring social well-being. Paris: OECD.

Pistor, K. (2006). Legal ground rules in coordinated and liberal market economies. In K. J. Hopt, E. Wymeersch, H. Kanda, \& H. Baum (Eds.), Corporate governance in context: Corporations, states, and markets in Europe, Japan, and the US (pp. 249-280). Oxford, New York: Oxford University Press.

Putnam, R. D. (2000). Bowling alone: The collapse and revival of American community. New York: Simon \& Schuster.
Rajan, R. G., \& Zingales, L. (1995). What do we know about capital structure? Some evidence from international data. Journal of Finance, 50(5), 1421-1460.

Reynolds, A. (1999). Women in the legislatures and executives of the world: Knocking at the highest glass ceiling. World Politics, 51(4), 547-572.

Reynolds, T. H., \& Flores, A. A. (1989). Foreign law: current sources of codes and basic legislation in jurisdictions of the world. Rothman: Littleton, Co (cited in La Porta et al. 1998).

Seashore, S. (1974). Job satisfaction as an indicator of the quality of employment. Social Indicators Research, 1, 135-168.

Shleifer, A., \& Vishny, R. W. (1997). Survey of corporate governance. The Journal of Finance, 52(2), 737-783.

Siems, M. (2005). What does not work in comparing securities laws: A critique on La Porta et al.'s methodology. International Company and Commercial Law Review, pp. 300-305.

Solomon, J. (2007). Corporate governance and accountability (2nd ed.). Chichester: Wiley.

UNICEF. (2004). The state of the world's children 2004. New York, NY: United Nations Children's Fund.

Wilkinson, R.G., \& Pickett, K. E. (2009). The spirit level: Why more equal societies almost always do better. London: Allen Lane.

Woodward, D., Edwards, P., \& Birkin, F. (2001). Some evidence on executives' views of corporate social responsibility. The British Accounting Review, 33(3), 357-397. 